\title{
BELGIAN POLITICS AND THE SPANISH CIVIL WAR
}

\author{
La política belga y la Guerra Civil española
}

\author{
Jorge Vargas Visús \\ Athénée Royal de Hannut (Bélgica) \\ jvvisus@yahoo.es \\ https://orcid.org/0000-0002-1619-866X
}

Recibido: 08-07-2020 - Aceptado: 14-02-2021

Cómo citar este artículo/Citation:

Jorge Vargas Visús, "Belgian politics and the Spanish

Civil War”, Hispania Nova, 20 (2022): 207 a 237.

DOI: https://doi.org/10.20318/hn.2022.6459
Copyright: (C) HISPANIA NOVA es una revista debidamente registrada, con ISSN 1138-7319 y Depósito Legal M 9472-1998. Los textos publicados están -si no se indica lo contrario- bajo una licencia Reconocimiento-Sin obras derivadas 3.0 España de Creative Commons. Puede copiarlos, distribuirlos y comunicarlos públicamente siempre que cite su autor y la revista y la institución que los publica y no haga con ellos obras derivadas. La licencia completa se puede consultar en: http://creativecommons.org/licenses/by-nd/3.0/es/deed.es

Resumen: A lo largo de la segunda mitad de la década de 1930, Bélgica y sus instituciones iban a verse puestas a prueba. El primer test serio vino dado por los sorprendentes resultados de las elecciones legislativas celebradas el 24 de mayo de 1936. El Rex de Léon Degrelle logró 21 escaños. En consecuencia, se conformó una nueva coalición de gobierno que buscó salvaguardar la estabilidad política. Al mismo tiempo, la remilitarización de Renania en marzo de 1936 modificó el panorama político europeo. Ante el nuevo escenario internacional, Bélgica redefinió su política exterior al objeto de liberar al país de sus compromisos internacionales determinados por los Tratados de Versalles y Locarno.

Ambos niveles políticos aparecen estrechamente conectados influyéndose mutuamente. Dada esta conexión, el debate político en Bélgica se vio distorsionado cuando se instaló en el terreno de las emociones provocadas por la guerra de España.

Palabras clave: Bélgica, Tratado de Locarno, PaulHenri Spaak, Politique d'indépendence, Guerra Civil española.
Abstract: During the second half of the 1930s, Belgium and its institutions were about to undergo testing. The first serious test came about after the shocking results of the legislative elections held on May 24, 1936. Léon Degrelle's party, the Rex, gained 21 seats. Consequently, a new coalition government had to be constituted in order to safeguard political stability. In parallel with this, a redefinition of the European political landscape was taking place due to the effects caused by the remilitarization of the Rhineland in March 1936. Vis-à-vis that new European scenario, the Belgian government decided upon a new foreign policy that aimed at liberating the country of its international commitments enshrined in the Versailles and Locarno treaties.

Both political levels were narrowly connected, influencing each other. Given this connection the Belgian political debate was distorted when it was transferred to the realm of emotions provoked by the Spanish conflict.

Keywords: Belgium, Locarno Treaty, Paul-Henri Spaak, Politique d'indépendance, Spanish Civil War. 


\section{INTRODUCTION}

According to a new historiographical approach developed during the last few years, Spain is not an exceptional case in Europe during the Interwar period. What happened in Spain was consistent with the political developments of the period. Dictatorship has been imposed over democracy in many European countries. Violence was a common means to solve political tensions generated by the dichotomy of revolution and counterrevolution. In some cases, violence led to civil war. Finland and Greece, as well as Spain, had to go through this traumatic experience. So, the Spanish Civil War is positioned within the framework of this European context. It must be understood, however, that an essential precondition of developments leading to civil war was constituted by a failed coup d'état, and therefore the emergence of a situation of "multiple sovereignty". That is to say, the presence of two contenders who had the military capability, as well as a solid social basis, who could therefore fight for power ${ }^{2}$.

With regard to the Interwar Period and World War II, Belgian historiography has addressed all their protagonists and miseries: Rexisme, Léon Degrelle, collaborationism, resistance, violence, and repression during the German occupation, etc. However, a comprehensive account of the impact of the Spanish Civil War on Belgian politics is missing, and therefore the available bibliography is rather limited. The writings or autobiographies by the witnesses of the events contain very few details related to the Spanish Civil War. Such is the case of the Minister of Foreign Affairs at the time, PaulHenri Spaak ${ }^{3}$; the Minister of Finance, Henri De $\mathrm{Man}^{4}$; as well as such prominent

\footnotetext{
${ }^{1}$ Charles Tilly, Las Revoluciones Europeas, 1492-1992, (Barcelona: Crítica, 2000), pp. 27-33.

${ }^{2}$ Works from historians such as Julián Casanova and Enrique Moradiellos are outstanding examples of this interpretation: Julián Casanova, España partida en dos, Barcelona, Crítica, 2013, pp. 12-18 y Enrique Moradiellos, El reñidero de Europa. Las dimensiones internacionales de la Guerra civil española, Barcelona, (Ediciones Península, 2014).

${ }^{3}$ Paul-Henri Spaak, Combats Inachevés, (Paris: Fayard, 1969).

${ }^{4}$ Henri De Man, Après Coup, (Brussels: Toison d'Or, 1941).
} 
officials of the Belgian Ministry of Foreign Affairs as Baron Van Zuylen ${ }^{5}$, Fernand Van Langenhove $^{6}$, further the President of the Parti Ouvrier Belge (POB) and Minister in the Van Zeeland cabinet until his resignation in January 1937, Emile Vandervelde ${ }^{7}$.

Considering historiography, Jose Gotovitch's article La Belgique et la Guerre Civile Espagnole : Un état des questions, written in 1983, offers the first academic account of the bibliographical panorama related to Belgium and the Spanish Civil War ${ }^{8}$. Gotovitch emphasizes that the available bibliography was scarce and that the very few papers that addressed this question represented barely the beginning of a research path.

In 1987, on the occasion of the 50th anniversary of the beginning of the Spanish Civil War, a number of Belgian historians contributed to a special issue of the Revue Belge d'Histoire Contemporaine ${ }^{9}$. The main purpose of this project was to give an account of the impact of the Spanish Civil War on Belgium. This volume offers merely a fragmented presentation of the topic. The articles propose suggestive reflections and departure points for further research that, for whatever reason, have not been carried out by Belgian historiography. Topics include Belgium's participation in the NonIntervention Committee, arms trafficking, the volunteers, etc. But the volume lacks a global vision of the Spanish Civil War as an influencing factor in Belgian politics and society. As Gotovitch explained in 1983, available primary sources were still waiting to be analysed in order to improve the narrative.

I would like to underline that, as yet, this topic has not awakened the interest of Spanish historians, although there are two exceptions. One is an article by Victor Fernández Soriano, offering the first approach describing the influence of the Spanish Civil War on Belgian politics ${ }^{10}$. His considerations are, however, limited to the first

\footnotetext{
${ }^{5}$ Pierre Van Zuylen, Les mains libres. Politique extérieur de la Belgique 1914-1940, (Brussels: L'Edition Universelle, 1950).

${ }^{6}$ Fernand Van Langenhove, "L'élaboration de la politique étrangère de la Belgique entre les deux guerres mondiales", Académie Royale de Belgique, Mémoires de la Classe des Lettres T. LXV, (1980): pp. 298302.

${ }^{7}$ Émile Vandervelde, Carnets 1934-1938, (Paris: Les Editions Internationales, 1966).

8 Jose Gotovitch, "La Belgique et la guerre civile d'Espagne: Un état des questions", Revue Belge d'Histoire Contemporaine 3-4 (1983): pp. 497-532.

${ }^{9}$ Revue Belge d'Histoire Contemporaine 1-2, 3-4 (1987).

${ }^{10}$ Víctor Fernández Soriano, "Bélgica y la Guerra Civil: el impacto del conflicto español en la política y la diplomacia de una pequeña potencia”, Cuadernos de Historia Contemporánea 29 (2007): pp. 219-233.
} 
months of the war only. The second is a paper by Marina Casanova that contains an account of the murder of Baron Jacques de Borchgrave ${ }^{11}$.

Given the limited bibliography, my research is based on archive research. Among other documents, it consists mainly of memoranda, diplomatic correspondence and reports, parliamentary minutes, minutes of party meetings, personal letters, and administrative reports that constitute the informational core of this work.

So, in the opinion of the author, it is plausible to conceive the Spanish Civil War as a significant influencing factor in Belgian politics. In the present work, I build a historical narrative incorporating three levels of analysis: first, on the dynamics of European history during the Interwar period; secondly, on Belgian political dynamics with regard to the Spanish Civil War; and, finally, on personal decisions made by individual actors involved in Belgian politics either by having official political responsibilities or by having a personal ideological commitment within this atmosphere of ideological confrontation. My purpose is to demonstrate how the Spanish Civil War acted as an influencing factor on the political life of Belgium. According to this approach, the evolving situation was a result of the fact that the political alternatives represented by the forces fighting in Spain were also present in Belgium. Furthermore, through the application of a comparative perspective, I want to contribute to the Spanish historiographical debate. The demonstration of the interconnection between the Spanish Civil War and Belgian politics places the Spanish conflict in the context of interwar Europe. As a consequence, developments in Spain could not be considered as an exception in Europe at that time.

\section{BELGIAN POLITICS AND THE SPANISH CIVIL WAR: AN INTRODUCTORY APPROACH}

From the last years of the 19th century until the beginning of World War I (WWI), Belgian liberal democracy was characterised by the political hegemony of Catholicism. This Catholic position was based on interclass coalitions that also allowed

\footnotetext{
${ }^{11}$ Marina Casanova, "Las relaciones diplomáticas hispano-belgas durante la Guerra Civil española: el caso del Barón de Borchgrave”, Espacio, Tiempo y Forma Serie V, Ha . Contemporanea, t. V (1992): pp. 293-302.
} 
the integration of the labour movement into the parliamentary system even before 1914: "the pre-war hegemony of clericalism was sustained and provided a stabilizing interclass coalition even in the more democratic context. In both countries (Belgium and the Netherlands) the confessional parties and trade unions absorbed a large fraction of the working class (...) The Catholic Unions in Belgium enrolled about 35 percent of the organized labour force" ${ }^{\prime 2}$. This circumstance avoided the radicalisation of the political left-wing. Therefore, Belgian Socialism refused to take the revolutionary path. Socialists understood that Catholicism was their antagonist in the issue of the mobilisation of the Belgian working class. So, the POB became a constitutional party before 1900 . These pre-war political developments allowed the Belgian parliamentary regime and its political parties to forge governmental coalitions as a means to contain extremist alternatives during the interwar period. But this was not an easy way to follow, as developments in Europe influenced Belgium's politics and threatened its domestic political stability.

One of these developments, the Spanish Civil War, broke out when Belgian political forces perceived a series of threats to the country and the state. With Hitler's rise to power in January 1933 his new aggressive foreign policy leading to the remilitarization of the Rhineland in March 1936 meant the presence of an increasingly powerful foreign army directly on the Belgian border. As a consequence, Belgian politicians started to fear a "new 1914". Therefore, the Belgian government decided upon a new foreign policy that aimed at liberating the country of its international commitments enshrined in the Versailles and Locarno treaties: The politique d'indépendence.

Concerning the state, the discontent caused by the economic crisis and apprehension over the spread of Communism encouraged the extreme right-wing alternative represented by Rex. Rexisme was seen by constitutional political parties as a real threat to Belgian parliamentary democracy. Consequently, governmental stability became a non-negotiable premise for every party participating in governmental coalitions between 1935 and 1939. Those were complicated years. Along with the rest of the countries of Europe, Belgium experienced political tensions generated by the

\footnotetext{
12 Gregory M. Luebbert, Liberalism, Fascism or Social democracy: Social classes and the Political Origins of Regimes in Interwar Europe, (New York: Oxford University Press, 1991), p. 248.
} 
increasing ideological polarisation in Europe. Hence, the Belgian state was challenged due to the influence of the international context and the domestic political panorama.

In Spain, the military attempt to overthrow the legal Republican government opened the door to the conflict. "In a state where neither the Fascists nor the Communists had been of any serious political significance, Spain became a battleground for these contending ideologies" 13 . The Spanish Civil War was seen as a battle between "good" and "evil", as a conflict in which extremist political alternatives were confronting each other, fighting to annihilate the opponent, to make sure that their own vision of how to organize the state and society prevailed. Belgian political actors interpreted the conflict in exactly the same way.

On the right side of the political spectrum, among the Catholic ranks, a religious vision of the conflict spread and was accepted without hesitation. In Spain, the failed military movement unleashed the social revolution it was supposed to eradicate. So, images of the repression against the Church, triggered on the Republican side during the first weeks of the war, were crucial to consolidating this interpretation. The Catholics' sympathies in Belgium were with the rebels. As for the Liberals, both considered that the Republican Spanish government was influenced and then controlled by Communists. The Belgian liberals' political agenda was marked by opposition to all political extremes. Since the Spanish Civil War represented the confrontation of the extremes, the Liberals maintained strict neutrality - but feared Communism more than the military alternative embodied by Franco.

On the left, the Parti Communiste Belge (PCB) was still a small party without real political influence. It was the POB that controlled the political left of the spectrum and was a real political alternative assuming governmental responsibilities. Both considered the Spanish Civil War as an aggression by Fascism against democracy.

Given these different interpretations with regard to the Spanish conflagration, the official position of the Belgian coalition government was to remain neutral and to align itself with the Non-Intervention policy proposed by the French government in August 1936. It was a position that conformed with the new foreign policy that aimed to

\footnotetext{
13 Zara Steiner, The triumph of the dark. European international history 1933-1939, (Oxford: Oxford University Press, 2011), p. 181.
} 
define a neutral status for Belgium within the European political framework. But, also, it was a foreign policy that pursued domestic stability in a situation where the Belgian state was challenged by authoritarian alternatives such as Rexisme. However, some prominent Socialist figures refused to adhere to this foreign policy. The POB and the governmental coalition's stability were about to undergo testing.

\section{6: THE SPANISH CIVIL WAR CAUSES POLITICAL TENSIONS IN BELGIUM}

While a part of the Spanish army was perpetrating a coup d'état against the legitimate government of the Spanish Republic on July 18, 1936, Belgium's government was redefining its foreign policy.

The remilitarization of the Rhineland in March 1936 at the order of Hitler meant the violation of the Locarno Treaty. The allegedly legitimate denunciation by Germany of the treaty was brought forward as a justification for the move. According to the argument of the German government, the Franco-Soviet Pact, signed in 1935, was in breach of the commitments contained in the Locarno Treaty and was to be considered as a threat to Germany's interests. Furthermore, Germany required that the new Nazi state be granted equal status within the European political framework ${ }^{14}$. Hitler's action exposed the division between the European policies of Britain and France ${ }^{15}$.

As a result of the remilitarization of the Rhineland, new negotiations aimed at reaching a new Western security pact began. However, this negotiation process was destined to fail. Italy and Germany found a way to mire European politics in the mud. The United Kingdom pursued as its main goal upholding the balance of power in Europe, a position that proved that the priorities of its foreign policy interests did not lie in Continental Europe ${ }^{16}$. That policy implied opposing French foreign policy as it had developed since the end of WWI - including the consent to Germany's demand to be

\footnotetext{
${ }^{14}$ Discours prononcé au Reichstag le 7 Mars 1936 par le Führer et Chancelier du Reich, Aldolf Hitler, 1936, Archives Diplomatiques Belges (hereafter ADB), Rhénanie 11309, p. 42.

${ }^{15}$ Since the end of WWI, Belgian diplomacy confirmed the confrontation between two European policies in regards to Germany. See Pierre Van Zuylen, Locarno et la politique belge, 1936, ADB, Locarno 11.115, p. 3.

${ }^{16}$ Zara Steiner, The triumph..., op. cit., p. 30.
} 
treated as any of the rest of the European powers. Accordingly, the new Locarno treaty was about to be negotiated under the following premise: Germany would be seated at the negotiation table as an equal partner ${ }^{17}$.

Vis-à-vis that new European scenario, Belgium's reaction was to modify its foreign policy. The Belgian government started withdrawing from the frontline of European diplomacy in order to get rid of some of the international commitments that, given the interests and capacities of the country, were considered excessive. For that reason, the starting point set out by the Belgian government to negotiate a new Locarno treaty - refusing to give guarantees but demanding to receive them - represented the beginning of Belgium's transition towards neutrality ${ }^{18}$. In order to avoid the accusation of disloyalty, this diplomatic withdrawal was disguised under the concept of politique d'indépendence, which was publicly announced and expounded in detail by the Belgian Minister of Foreign Affairs, Paul-Henri Spaak, on July 20, $1936^{19}$.

This act was justified not only by invoking the necessity of recovering the secular role of Belgium as a barrier state - avoiding conflicts between European powers and therefore safeguarding European peace ${ }^{20}$ - but also by invoking the necessity of guaranteeing the national unity of Belgium. The Belgian government insisted upon the necessity of working for the state's internal stability ${ }^{21}$. In this sense, in addition to the political complications generated by the Flemish question, the Belgian government had to confront the political polarization caused by the new strength of the political alternatives originating from the margins of the political spectrum. Belgium had not been spared the consequences of the Revolution-Counterrevolution dichotomy that had

\footnotetext{
${ }^{17}$ The British government wanted Germany to be integrated within the post-war international system in order to preserve a stable and economically healthy Europe. See Germany and the Locarno Treaty. Memorandum by the Secretary of State for Foreign Affairs, 1936, The National Archives (hereafter NA), The cabinet papers, CP 73 (36), pp. 1-6, http://filestore.nationalarchives.gov.uk/pdfs/small/cab-24-261CP-73-2.pdf [accessed November 2, 2016].

${ }^{18}$ Examen critique des principales formules à envisager en vue de la révision du pacte Rhénan, 1936, ADB, Locarno 11.115.

${ }^{19}$ Réunion diplomatique, 1936, ADB, 11.179 (3), p. 6. See also Discours prononcé le 20 Juillet 1936, à l'Union de la Presse Etrangère, à Bruxelles, par M. Spaak, Ministre des Affaires Etrangères et du Commerce Extérieur, 1936, ADB, Locarno 11.115, Circulaire d'information №52.

${ }^{20}$ Fernand Van Langenhove, Note sur le principe de la securité collective et l'assistance mutuelle, 1936, ADB, 11.179 (3).

${ }^{21}$ Paul-Henri SPAAK, Projet, ADB, 1936, Rhénanie 11.115, p. 2.
} 
been spreading all over Europe since the end of WWI. The Belgian state and its institutions were about to undergo testing.

The first serious test came about after the shocking results of the legislative elections held on May 24,1936. Léon Degrelle's party, the Rex, gained 21 seats. Consequently, a new coalition government composed by the POB, the Catholics and the Liberals had to be constituted in order to safeguard political stability and to contain Rex's political ambitions ${ }^{22}$.

In parallel with this domestic challenge, the new governmental coalition had to steer the country through the turbulent waters of European politics. Therefore, in the new Locarno negotiations, Belgium had a very well-defined political goal: to determine a new international status based on receiving guarantees from the major European powers while not giving them to other states.

Yet when the negotiation process began, a new obstacle to Belgium's interests arose: a coup d'état perpetrated by General Franco in Spain led to a civil war that shattered the European political panorama ${ }^{23}$. So, the Belgian government defined an extremely prudent policy relating to the Spanish conflict. The Minister for Foreign Affairs, Paul-Henri Spaak, subordinated his political moves to the great powers' decisions and guaranteed Belgium's non-intervention in hostilities ${ }^{24}$. A political position sustained also by the Liberals and the Catholics. Both considered that the Spanish Civil War could provoke the division of Europe and the subsequent European conflagration ${ }^{25}$.

Accordingly, Belgium proceeded to update its legislation on arms trafficking in order to comply with the Non-Intervention agreement negotiated by the European powers in August 1936.

\footnotetext{
${ }^{22}$ A new coalition government under the Catholic Prime Minister Paul Van Zeeland.

${ }^{23}$ Archives Générales du Royaume (hereafter AGR), Procès verbaux du Conseil des Ministres N²6, 14/10/1936, p. 291, http://extranet.arch.be/510 $1527 \quad 000 \quad$ B/510 $1527 \quad 000 \quad 04629 \quad 000 / 510 \quad 1527 \quad 000 \quad 04629 \quad 000 \quad 00 \quad 002$ 0.pdf\#search $=\% 22 \% 22$ [accessed July 10, 2016].

24 AGR, Procès verbaux du Conseil des Ministres $N^{\mathrm{o}} 18,28 / 08 / 1936$, p. 236, http://extranet.arch.be/510 $1527 \quad 000 \quad$ B/510 $1527 \quad 000 \quad 04628 \quad 000 / 510 \quad 1527 \quad 000 \quad 04628 \quad 000 \quad 00 \quad 055$ 0. pdf\#search $=\% 22 \% 22$ [accessed July 10, 2016].

${ }^{25}$ Laveleye, "La non-intervention en Espagne", La Dernière Heure, August 27, 1936. See also Struye, "La guerre civile d'Espagne au regard du Droit International", La Libre Belgique, August 22, 1936.
} 
Belgium agreed to the Non-Intervention Pact on August 28. Yet the Belgian government had previously updated the arms trafficking legislation through the promulgation of two decrees. It did so following earlier decisions taken by the main European governments on this particular issue in regards to the Spanish war ${ }^{26}$. First, the Arrêté Royal on August 4, published in the Moniteur Belge on August 5, meant that exports of weapons, components for weapons, and all kinds of ammunition were subject to a concession of a license by the Minister of Economy or his delegate ${ }^{27}$. Barely two weeks later, with the aim of extending the legislation's scope, the government promulgated another Arrêté Royal, on August 19, subordinating the export and also the transit of weapons, ammunition, and war materiel to a concession of a license ${ }^{28}$.

Even before Belgium joined the Non-Intervention Pact on August 28, Van Zeeland's government was doing its utmost to apply this new legislation in order to avoid any possible international complications caused by arms trafficking to Spain $^{29}$.

Both measures as well as the Belgian government's resolve to comply with them were communicated to the Non-Intervention committee by the Belgian representative, Baron de Cartier ${ }^{30}$. At the end of October 1936, Belgium reinforced its neutral position toward the Spanish war when its government supported the British proposal to establish a surveillance system over arms trafficking into $\operatorname{Spain}^{31}$.

The last measure contributing to Belgian neutrality towards the Civil War, that was taken in December 1936, was related to the recruitment of volunteers to fight in Spain. Van Zeeland's government agreed with the British proposal to extend the NonIntervention's scope also to this particular issue ${ }^{32}$.

\footnotetext{
${ }^{26}$ Fernand Van Langenhove, "Note sur les fournitures d'armes à l'Espagne”, 1936, ADB, Espagne-Guerre civile, Comité de Londres 11.157.

${ }^{27}$ Conflit politique en Espagne. Mesures prises par le Gouvernement belge en matière d'exportation d'armes de guerre, 1936, ADB, Espagne-Guerre civile, Comité de Londres 11.157, Circulaire d'Information No54.

${ }^{28}$ Moniteur Belge No23, 1936, ADB, Espagne-Guerre civile, Comité de Londres 11.157, p. 5456.

${ }^{29}$ Fraikin, lettres No220/51 et No220/52, 1936, ADB, Espagne-Guerre civile, Comité de Londres 11.157.

${ }^{30}$ Télégramme 96, 26/09/1936, ADB, Espagne-Guerre civile, Comité de Londres 11.157.

${ }^{31}$ Télégramme №112, 28/10/1936, ADB, Espagne-Guerre civile, Comité de Londres 11.157.

32 The Committee approved it on December 9, 1936. Belgium adapted its legislation which came into effect from Mars 6, 1937 in Bulletin Périodique de la Presse Belge Nº125, 1937, Bibliothèque Nationale
} 
The problem of volunteers was a cause for concern for the Belgian government even before the Committee's decision. Since the middle of November, Van Zeeland's cabinet had been acting on its own military legislation ${ }^{33}$. But once the British proposal was approved by the Non-Intervention Committee, Belgium elaborated and approved $a d$ hoc legislation to guarantee the prohibition of all kinds of interventions, direct or indirect ${ }^{34}$.

The controversies that the new politique d'indépendence provoked in some political circles were brought into the spotlight by the Spanish Civil War. As a consequence, polemics and bitter debates took place, making the new foreign policy part of the internal political debate. That is to say, the debate on the politique d'indépendence and on the Spanish Civil War set off a political battle and a propaganda war where the control of the state's institutions could be the potential prize for the winner. The communists and a significant number of socialists considered the politique d'indépendence to be a mistake ${ }^{35}$. They thought that it opened the door to a European conflagration as it gave way to revisionist demands and ambitions of the authoritarian and fascist regimes ${ }^{36}$. They pointed to the Spanish war as a perfect example of such reasoning ${ }^{37}$. Indeed, on the other hand, this conflict was seen by Rex as the way to proceed on its path to power ${ }^{38}$.

The Spanish Civil War internationalized rapidly. The violent confrontation of the political alternatives in Spain had their replica within the European political landscape. In this sense, Belgium's domestic politics also had an international dimension: The

de France (hereafter BNF), p. 10, http://gallica.bnf.fr/ark:/12148/bpt6k64198838.item [accessed June 16, 2015].

33 Verspecht, Non-Intervention en Espagne, 1936, ADB, Espagne-Guerre civile, Comité de Londres $11.157(3)$.

${ }^{34}$ Eric David, "La condition juridique des volontaires belges pendant la guerre d'Espagne (1936-1939)", Revue Belge d'Histoire Contemporaine 1-2 (1987): pp. 66-69.

${ }^{35}$ AMSAB-ISG, Comptes Rendus POB, Doc. 1936-07-27_bwp_AR.pdf, p. 5, http://opac.amsab.be/digital/59990D3B-2DF5-4F41-B08E-6ED18CFF9B7A.pdf) [accessed March 17, 2015].

36 “Jacquemotte ataque énergiquement le discours pro-hitlerien de P. H. Spaak", Le Drapeau Rouge, August 1, 1936.

${ }^{37}$ AMSAB-ISG, Comptes Rendus POB, Doc. 1936-07-27_bwp_AR.pdf, p. 5, http://opac.amsab.be/digital/59990D3B-2DF5-4F41-B08E-6ED18CFF9B7A.pdf) [accessed March 17, 2015].

38 “Les clases moyennes. Rempart social du pays”, Le Pays Réel, July 28, 1936. 
Rexists' political slogan Rex ou Moscou, or the Liberals' response to it contre Rex et Moscou, linked Belgian political actors to the political alternatives that had been appearing in Europe since the 1920s and were involved in the fighting in Spain.

Given this connection between the European political situation and the Belgian political landscape, the Spanish Civil War became a plausible scenario for the future of Belgium. The question "What could happen if...?" had a realistic base and therefore the political debate was distorted when it was transferred to the realm of emotions.

Consequently, the Spanish Civil War had significant effects in Belgium. For instance, in regards to the POB, the new foreign policy of the government of Belgium and so its implementation with regards to the Spanish war - provoked a schism within the party.

The experience of 1914 determined the position of both Emile Vandervelde and the De Man and Spaak duo concerning the new political situation in Europe. Despite the fact that they shared the main political goal, that is to say keeping Belgium from becoming involved in a new war, they diverged in the way they wanted it to be achieved. Vandervelde advocated for Belgium to stay within the collective security system of the Locarno Treaty. Consequently, he wanted Belgium to respect the international relations framework determined by the League of Nations. Following the action line defined by both the Socialist International and the International Federation of Trade Unions, he put pressure on the Belgian government to face fascist powers firmly ${ }^{39}$. For the POB's President, the failure of International Socialism was to be avoided at any cost, as it was the case in 1914 as a consequence of neglecting the solidarity principle and failing to oppose military mobilization and conflict.

On the other hand, De Man and Spaak aligned with the intentions of both the coalition government and King Leopold III $^{40}$ to define an independent foreign policy that, in regards to Spain, meant alignment with the Non-Intervention policy for the sake

\footnotetext{
39 "Le Congrès du POB", Informations Internationales, Institute Emile Vandervelde (hereafter IEV), INF/IN/0/433 Vol. XIII, No. 44, p. 426.

${ }^{40}$ King Leopold III aligned with Van Zeeland's government foreign policy. He asserted his position during a cabinet meeting held on October 14, 1936. The King's speech reproduced in AGR, 1936, Procès Verbaux du Conseil des Ministres BE-A0510 / I 252/04.
} 
of maintaining the peace in Europe by not provoking the fascist powers ${ }^{41}$. A policy contributing with the appeasement policy implemented by the United Kingdom and France during the years before the Second World War. Concerning Belgium: its national imperatives that defined the new foreign policy were determined by the fear of another invasion of the country. This was a plausible possibility, since Hitler had remilitarized the Rhineland in March $1936^{42}$.

A latent hostility broke out between the two political positions when the Spanish Civil War broke out ${ }^{43}$. The Non-Intervention policy proposed by France in regards to the Spanish Civil War converged with the political intentions of the Van Zeeland administration to develop an independent foreign policy. It is about this issue that the disagreement between Vandervelde and Spaak spread to the Spanish conflict.

This was a disagreement that, fortunately for the coalition government, was limited to the POB's ranks and reached neither the Liberals nor the Catholics. The former, beyond their adherence to the politique d'indépendence and by its extension to the Non-Intervention policy, did not pay as much attention to the international situation as the socialists and communists did. Their political battle took place at home. Their opponent: Rex. Since the entry of Rex to the Belgian Parliament, the Liberal party prioritized its political action in trying to avoid Rex taking power. The Liberal party's main political goal was to contain Rex's political agenda ${ }^{44}$. For that reason, in their internal debates the Liberals did not pay too much attention to the political significance of the Spanish conflict, although it was exactly the Liberal press that offered reflections and opinions about what was happening in Spain.

For their part, the Catholics were absorbed in a party crisis due to the electoral results of the legislative elections held in May. Beyond their support of the policies of the coalition government, the Catholic Bloc did not make too much noise concerning

\footnotetext{
${ }^{41}$ AGR, Procès verbaux du Conseil des Ministres, No26, 14/10/1936, p. 294, http://extranet.arch.be/510_1527 $000 \quad$ B/510 $1527 \quad 000 \quad 04629 \quad 000 / 510 \quad 1527 \quad 000 \quad 04629 \quad 000 \quad 00 \_002$ 0.pdf\#search $=\% 22 \% 22$ [accessed July 10, 2016].

${ }^{42}$ Conversation du Roi avec M. A. Eden, Historical Archives of the European Union (hereafter HAEU), PHS-11 1936-1937, Doc. 0194, http://archives.eui.eu/en/fonds/187973?item=PHS-01-15 [accessed December 19, 2016].

${ }^{43}$ Paul-Henri SPAAK, Combats..., op. cit. p. 29.

${ }^{44}$ Assamblée Générale statutaire du 2 Mai 1937. Rapport du President, 1937, Archives de 1'ULB, Paul Hymans, PP001/1/324.
} 
echoes arriving from Spain. Of course, the Catholic press accepted the propaganda battle that had settled over Belgian public opinion and took sides with the Spanish rebels, denouncing the communist danger ${ }^{45}$. For its part, however, the Church did not declare itself until the end of the year. In December 1936 it published a pastoral letter denouncing the communist danger materializing in Spain. Yet the letter also contained an implicit warning about right-wing authoritarianism that could become a reality in Belgium through Rex ${ }^{46}$.

The Rex made intensive efforts to project the Spanish conflict onto Belgian reality. The Spanish Civil War was used by Degrelle as a propaganda tool to discredit moderate Belgian political parties. He accused the Spanish traditional right-wing parties of being responsible for the outbreak of the revolution in Spain. By doing that, he extended this conclusion to blame the Belgian traditional parties - Liberals and Catholics - for the socialist electoral victory and the progress of the Communists in May. This simple reasoning constituted the core of Rex's slogan Rex ou Moscou by which Degrelle's party attempted to polarize Belgium's political landscape and discredit its political opponents ${ }^{47}$.

The political polarization did not benefit the PCB. In Spain the Revolution was unleashed in some territories under the Republic's authority. The images of revolutionary excesses gave powerful propaganda ammunition to anyone who wanted to use it against the $\mathrm{PCB}^{48}$. For a party whose principal aspiration was yet to become a mass party ${ }^{49}$, a polemic over a military conflict, where Communist ideology was a fundamental actor, reduced its possibilities to grow.

So, during the second half of 1936, political tensions increased in Belgium due to the political impact of the Spanish Civil War and led to the first major political crisis. Emile Vandervelde honored his promise and did everything in his power to help his

\footnotetext{
45 “La guerre civile en Espagne”, La Libre Belgique, July 25, 1936.

${ }^{46}$ Bulletin Périodique de la Presse Belge No125, 1937, BNF, pp. 11-12, http://gallica.bnf.fr/ark:/12148/bpt6k64198838.item [accessed June 16, 2015].

${ }^{47}$ Degrelle, “Rex ou Moscou?”, Le Pays Réel, July 27, 1936.

48 "L’intervention de l'International moscoutaire en Espagne”, La Libre Belgique, August 17, 1936.

${ }^{49}$ Doc. AVTG/169, 1936, CArCoB asbl, Archives Avant-Guerre 1933-1937, p. 1.
} 
Spanish comrades ${ }^{50}$ and, therefore, provoked a government crisis on the basis of the Affaire Borchgrave.

\section{7: POLITICAL BALANCES}

In January 1937 the German Chancellor, Adolf Hitler, gave a speech that fed Belgian hopes to see its new desired international position, liberated from the old Locarno engagements, recognized ${ }^{51}$. On the other hand, the British and French finally accepted that the Belgian strategic fundamentals with regard to the state's foreign policy had been redefined and, above all, they understood that Belgium had no intention of backing down.

The British Foreign Secretary, Anthony Eden, yielded to the evidence during an interview with King Leopold III in London on January 1937. During the conversation, Leopold justified Spaak's foreign policy by arguing that Belgium's aim was to maintain good and balanced relations with its neighbors. Leopold didn't hide the fact that fear was acting as a guiding principle for the new Belgian foreign policy ${ }^{52}$. Although Eden replied to the king that war was inevitable, Belgium's intentions to remain firm with its politique d'indépendence were accepted by the British and French. So, at the end of March, both agreed to proceed with exempting Belgium from its Locarno obligations ${ }^{53}$.

The United Kingdom and France agreed to publish a statement recognizing the new Belgian foreign policy and thus liberating Belgium from its Locarno obligations without compromising its security guarantees and territorial inviolability ${ }^{54}$.

Belgium's government rid itself of a very unpleasant burden given both the isolationist and neutralist trends present in the context of Belgian domestic politics and the fear of the country being dragged into a new European war when the statement was

\footnotetext{
50 “Le Congrès du POB”, Informations Internationales, IEV, INF/IN/0/433 Vol. XIII No. 44, p. 426.

${ }^{51}$ Bulletin Périodique de la Presse Belge No125, 1937, BNF, p. 4, http://gallica.bnf.fr/ark:/12148/bpt6k64198838.item, [accessed June 16, 2015].

${ }^{52}$ Télégramme téléphoné $\mathrm{N}^{\mathrm{o}}$ 7, 30/01/1937, ADB, 11.179 (3 bis).

${ }^{53}$ Note sur la déclaration franco-britanique et sur la déclaration allemande concernant la Belgique, 1937, ADB, Locarno, 11.115, p. 4.

54 Circulaire d'information personnelle $N^{o}$ 5: Nouveau statut international de la Belgique. Note Britanique et Française du 24 Avril 1937, 1937, ADB, Locarno 11.115.
} 
published on April 24, $1937^{55}$. With the declaration of the Reich's government of its intention to respect the territorial integrity of Belgium on October 13, 1937, an ideal scenario for Van Zeeland's government was thus consolidated ${ }^{56}$.

Paul-Henri Spaak considered the German statement as carrying the same weight as those of the French and British. Equally, he thought that it signified the end of the period of military alliances for Belgium. That is to say that through its politique d'indépendence the country had free rein to focus exclusively on its own interests and priorities $^{57}$.

Negotiations with the Locarno powers were not easy. The new Belgian diplomatic position surprised the French and British ${ }^{58}$. Therefore, the Belgian diplomatic service, including Spaak and Van Zeeland themselves, were under heavy pressure to reverse their decisions in regard to Belgian foreign policy. They had to stand up for their new position, and at the same time avoid being accused of disloyalty ${ }^{59}$. The diplomatic contacts between Belgium and Germany themselves created a very uncomfortable situation for the Belgians by giving rise to suspicions among the British and French. All in all, both countries provided Belgium with their precious guarantees of security and territorial inviolability and integrity ${ }^{60}$.

The Spanish Civil War and the subsequent acceptance of the Non-Intervention policy, joined into by the Belgian government, became heavy obstacles for the implementation of the politique d'indépendence. With respect to the Spanish conflict, Belgium kept the extremely prudent line of action defined since the country had adhered to the initiative in August 1936. So prudent that, on some occasions, Spaak intentionally let circumstances decide on his behalf in order to avoid decisions that could compromise

\footnotetext{
${ }^{55}$ Gazel, Rapport Nº92 (1), 1937, AGR, Marcel-Henri Jaspar I 226-1923.

${ }^{56}$ Reproduced in Anex B Circulaire d'information No59: Déclaration du Gouvernement allemand sur l'inviolabilité et l'integrité de la Belgique, 1937, ADB, Locarno 11.115.

${ }^{57}$ Note sur la déclaration franco-britanique et sur la déclaration allemande concernant la Belgique, 1937, ADB, Locarno, 11.115, p. 10.

${ }^{58}$ Rapport T. N 528 bis, 1936, AGR, Marcel-Henri Jaspar, I 226-1923.

${ }^{59}$ Ibidem., p. 4.

${ }^{60}$ Preparations for the proposed five power conference, 1936, NA, The cabinet papers, C. P. 284 (36), p. 5, http://discovery.nationalarchives.gov.uk/details/r/D7730663 [accessed November 2, 2016].
} 
Belgium's foreign political position ${ }^{61}$. This line of action was not driven by a deep concern about the Non-Intervention policy but rather by Belgium's interests with respect to the negotiations of Locarno. Belgium did not want to endanger its negotiating position concerning Locarno by taking decisions that could be understood as taking a position on the Spanish War. Belgium was part of the Non-Intervention Committee just in order to implement the initiatives taken within that forum. Moreover, Belgium tried not to take an active part in certain decisions ${ }^{62}$. Within the Non-Intervention framework, Belgium played the role of a high-performing diligent student. Following this path, during the year 1937, the country succeeded in balancing its international position and completing the implementation of its new foreign policy.

On the other side, balance was also needed in domestic politics. First, the new alternative represented by Rex was perceived as a threat to the state ${ }^{63}$. Secondly, both the new foreign policy and the political decisions taken in relation to the Spanish conflict opened violent rifts within the POB that threatened the party's stability and consequently that of the coalition government.

Thus 1937 required that a political balance be found in order to guarantee political stability to reinforce the coalition government and to minimize threats to the state. January began with a diplomatic and, as a consequence, governmental crisis provoked by the assassination of Baron de Borchgrave in Spain ${ }^{64}$. The Prime Minister, Paul Van Zeeland, contained the crisis by forcing the unruliest minister in the cabinet on Spanish issues, Emile Vandervelde, to resign ${ }^{65}$.

Once this crisis was resolved, the threat posed by Rex had to be contained, too. During the first months of 1937, Degrelle and his followers strained parliamentary life

\footnotetext{
${ }^{61}$ Note sur la création d'un organismo de contrôle aux frontières espagnoles, 1937, ADB, EspagneGuerre civile, Comité de Londres 11.157 (5).

${ }^{62}$ Verspecht, 1937, ADB, Espagne-Guerre civile, Comité de Londres 11.157 (6). See also Note pour Monsieur Boseret, 1937, ADB, Espagne-Guerre civile, Comité de Londres 11.157 (7).

63 "Pour la liberté. Contre la guerre civile", Le Soir, March 11, 1937.

${ }^{64}$ Affaire Borchgrave, Arrêt 6/11/1937, Permanent Court of International Justice, Série A/B Arrêts, Ordonnances et Avis Consultatifs, A/B72 (http://www.icj-cij.org/pcij/series-a-b.php?p1=9\&p2=3 [accessed January 6, 2016].

${ }^{65}$ For a complete account on this political crisis see Séance du Conseil Général du POB 10/02/1937, IEV, Conseil Générale du POB 1935-1938.
} 
and sought to make Belgian public opinion wake up ${ }^{66}$. When Rex felt ready to seize power, they set about creating the circumstances that would allow them to do it. In March, Rex forced the calling of partial elections in Brussels ${ }^{67}$. Degrelle announced his candidature to the Parliament ${ }^{68}$. The remaining political parties chose not to present their own candidates and united in a coalition around Van Zeeland's candidature. Degrelle's move resulted in a defeat that consolidated the coalition government and that also sent a clear message about the strength of the structures of the Belgian state ${ }^{69}$. It was a strength buttressed by important supports - such as that of the Belgian Catholic Church $^{70}$ - that allowed the Belgian state to resist political challenges that succeeded in other European countries or, as was the case in Spain, provoked a civil war ${ }^{71}$. After these partial elections, the domestic political situation stabilized once some leaks that allowed the extreme right to increase their electoral support were sealed.

Another fire that threatened to spread out of control flared up within the POB. In January the Borchgrave affair exposed the internal fractures within the party. The more prominent POB members assumed responsibility for this political fracture and worked to avoid causing trouble in the coalition government. In that sense the resolution of the POB General Council of January 27, 1937 was essential to stabilizing the situation within the party. By this resolution the POB gave priority to continuing its membership in the coalition government ${ }^{72}$. In practical terms the resolution meant a rupture with the

\footnotetext{
${ }^{66}$ About the Affaire Huysmans see Archives de l'ULB, Paul Hymans, BR 2/241.

67 “Aujourd'hui, à dix-sept heures, au Palais des Sports: déclaration sensationnelle de Léon Degrelle”, Le Pays Réel, March 7, 1937.

68 “La nation doit parler”, Le Pays Réel, March 8, 1937.

${ }^{69}$ Pascal Delwit, La vie politique en Belgique de 1830 à nos jours (Brussels: Editions de 1'Université de Bruxelles, 2012), p. 117.

${ }^{70}$ About Belgian Church's position in respect with Rex see Robert PFEIFFER and Jean LADRIERE, L'aventure rexiste (Brussels 1966), pp. 117-118.

${ }^{71}$ Gregory M. Luebbert, Liberalism..., op. cit. pp. 1-11.

72 Doc. 1937-01-27_bwp_BU.pdf, AMSAB-ISG, Comptes Rendus POB, p. 61 http://opac.amsab.be/digital/73D8B1BB-70CB-4D55-9B08-03EBB8979BBA.pdf [accessed March 17, 2015].
} 
political tradition of the POB. For the first time, the distinction between government action and party action was accepted by the POB's ranks ${ }^{73}$.

However, passions raised by the war were so intense that they were impossible to be ignored ${ }^{74}$. The Socialists required something else to be done. They had to be in Spain to make their presence felt because the PCB was intensely involved with the recruitment of volunteers and the collection of material aid to be sent to the Spanish republic $^{75}$. Therefore, solidarity initiatives in which the POB got involved were crucial to compete politically with the PCB and to avoid political energies being deployed for an all-out internal political battle ${ }^{76}$. This would be a battle that could have led to unsupportable instability for the coalition government - just like the Borchgrave affair at the beginning of that year. Even though debates about the Spanish war continued during party meetings, 1937 was the year in which the POB succeeded in establishing and maintaining a political balance in relation to the Spanish Civil War.

A political balance ensued due to both the recognition by the internationalist faction that they couldn't influence the government's foreign policy ${ }^{77}$ and the efforts of Spaak and De Man to avoid a revolt within the party that could threat the coalition government $^{78}$. This new status quo was clearly reflected in the content of the resolution

\footnotetext{
${ }^{73}$ Doc. 1937-02-08_bwp_BU.pdf, AMSAB-ISG, Comptes Rendus POB, p. 82 http://opac.amsab.be/digital/3E50EB1C-9A7B-4DEF-A043-02BA34B1CA0E.pdf [accessed March 17, 2015].

${ }^{74}$ Doc. 1937-02-05_bwp_BU.pdf, AMSAB-ISG, Comptes Rendus POB, pp. 74-78 http://opac.amsab.be/digital/4223353A-57D2-4F19-8BED-01A70DFCB736.pdf [accessed March 17, 2015].

${ }^{75}$ Doc. 1937-02-08_bwp_BU.pdf, AMSAB-ISG, Comptes Rendus POB, pp. 80-86 http://opac.amsab.be/digital/3E50EB1C-9A7B-4DEF-A043-02BA34B1CA0E.pdf [accessed March 17, 2015].

${ }^{76}$ Séance du Conseil Général du 18/02/1937, IEV, Conseil Général du POB 1935-1938, p. 9.
}

The socialist Senator, Arthur Jauniaux proposed a resolution aiming to create a Commision for Relief. See Seance du Conseil Général du 13/07/1937, IEV, Conseil Générale du POB 1935-1938, p. 57.

For more details about socialist's solidarity initiatives see Nicolas Lépine, "Le socialisme international et la Guerre Civile espagnole", (Ph. D. thesis, L'Université Laval Quebec, 2013), pp. 244-268. http://hdl.handle.net/20.500.11794/24897

${ }^{77}$ Doc. 1937-07-13_bwp_BU.pdf, AMSAB-ISG, Comptes Rendus POB, p. 13a http://opac.amsab.be/digital/09C28DD9-0AB1-4029-8B3D-17FD95B01E93.pdf [accessed March 17, 2015].

${ }^{78}$ For that reason, Spaak urged the party to break with POB's tradition and therefore to distinguish between government action and party action. See Doc. 1937-02-08_bwp_BU.pdf, AMSAB-ISG, Comptes 
adopted by the POB's General Council during the session held on July $23,1937^{79}$. The resolution established, without going into details about how to achieve its objectives, namely that governments of the member states of the League of Nations had to be compelled to assist the Spanish government in recovering its territorial independence. Equally, the resolution advocated re-establishing trade freedom in order to allow the Spanish republic to acquire arms to defend its territory. Finally, it proposed extending solidarity obligations with the Spanish cause to all activists and organizations that adhered to the Labor and Socialist International (LSI) and the International Federation of Trade Unions (IFTU).

In brief, Spaak's foreign policy was imposed over the internationalist's alternative. Nevertheless, despite the supremacy of De Man and Spaak's political line, during 1938 a last political battle on the Spanish Civil War, within the POB but transcending the party's limits, was about to be unleashed: The Burgos Question.

\section{8: THE BURGOS QUESTION}

The political fire that had flared up in 1936 and been put under control in 1937 revived in 1938. The still intense passions of the internationalist faction of the POB threatened Spaak's government. Despite that, in March 1938 he finally succeeded in gaining his party's support of his foreign policy. But the symbolism of the decision to send a commercial representative to Francoist Spain acted, for a large number of socialists, as a catalyst for the propagation of a new wave of infighting.

Spaak was put under pressure to change his political position vis à vis the Spanish rebels quite early. In October 1936 the Belgian ambassador to Spain, Robert Everts, reported his concerns about the possible consequences of a military victory by the rebels ${ }^{80}$.

The debate about acknowledging the Spanish rebels gained intensity in Brussels during the summer of 1937. On July 9, the rebels' informal representative, Ernesto de

Rendus POB, p. 82, http://opac.amsab.be/digital/3E50EB1C-9A7B-4DEF-A043-02BA34B1CA0E.pdf) [accessed March 17, 2015].

79 “Le POB et l'Espagne”, Informations Internationales, IEV, INF/IN/0/433 Vol XIV No. 9, p. 80.

${ }^{80}$ La question de la reconnaissance du gouvernement nationaliste, 1936, ADB, Reconnaissance de Burgos, 11.169 (1). 
Zulueta e Isasi, sent a note verbale to the Belgian government demanding the rebels' right of belligerence to be acknowledged by Belgium ${ }^{81}$.

That same year, at the beginning of September, a group of industrialists took for granted that Belgian foreign relations with the Francoist authorities were going to remain tense, so they urged Spaak to follow the example of countries such as the United Kingdom, Switzerland, and the Netherlands that, according to their testimony, had established a modus vivendi with the rebels: a modus vivendi implying recognition official or unofficial - of Franco's Spain ${ }^{82}$.

In December, Everts was informed about the accreditation of Portuguese agents and also about the negotiations in order to establish commercial relations that, following the example of the United Kingdom, were taking place between the rebels and the United States of America ${ }^{83}$.

During that same month, pressure from inside the Belgian Ministry of Foreign Affairs started to be felt. Baron Van Zuylen argued in favor of establishing relations with the rebels in order to defend Belgian economic interests in Francoist Spain ${ }^{84}$. He would remind the Baron that the total value of Belgian capital investments in Spain had already reached 3.7 billion francs; that, between private and trade credits, 445 million francs were committed and, according to Everts' information, a loss of business was already a fact because Franco had prioritized commercial relationships with countries having an official or unofficial representation in the territory controlled by his army ${ }^{85}$.

Therefore, Spaak's subordinate urged him to change his position in the matter of sending a commercial representative to Francoist Spain. Van Zuylen reminded Spaak of the fact that the principle of Non-Intervention did not prohibit the possibility of having

\footnotetext{
${ }^{81}$ Zulueta offered to the Belgian government a reward, under the form of commercial advantages, in exchange of the acknowledgment. See Etat de la question de la reconnaissance du Gouvernement de Salamanque, 1937, ADB, Reconnaissance de Burgos 11.169 (1), pp. 6-7.

${ }^{82}$ Lettre du Comité Central Industriel de Belgique à Spaak, 1937, ADB, Reconnaissance de Burgos 11.169 (1).

${ }^{83}$ Répresentation du Portugal auprès du Gouvernement de Salamanque $N^{o}$ 748/372, 1937, ADB, Espagne-Guerre civile, Correspondance Politique 11.059.

Pourparlers en vue d'établir des relations commerciales entre les Etats Unis et l'Espagne nationaliste $N^{o}$ 758/377, 1937, ADB, Espagne-Guerre civile, Correspondance Politique 11.059.

${ }^{84}$ Note pour Monsieur le Ministre, 1937, ADB, Reconnaissance de Burgos 11.169 (1), p. 1.

${ }^{85}$ Ibidem., p. 4.
} 
business relations with the Spanish rebels. On this matter the evidence was that the majority of the countries that maintained - unofficial - business relations with Franco were signatories to the Non-Intervention pact ${ }^{86}$.

However, with regard to this question, there were objections, too. A study that reached the officials of the Ministry of Foreign Affairs questioned the necessity of sending a commercial representative to $\operatorname{Burgos}^{87}$.

So, two positions were defined on an issue that was also discussed in Parliament before the end of 1937. During the plenary session of the Senate held on December 9, the Catholic senator d'Aspremont-Lynden had argued that commercial relations with Francoist authorities should be established. He did so by appealing to the defense of Belgian economic interests, the majority of them lying, according to his explanation, within the rebel's territory ${ }^{88}$. The Catholic politician presented, as examples to be followed, states such as the United Kingdom, Switzerland, the Netherlands, Yugoslavia, Romania, Austria, and Hungary, with some of them having consular relations with Franco's government.

The response from the POB was not long in coming. Emile Vandervelde publicly responded to this proposal through an article published by Le Peuple ${ }^{89}$. The POB leader was confident that the government would give a negative response to d'Aspremont-Lynden's demand. Equally he denounced what he considered hidden intentions to send subversive elements to Spain to act against the republican government. In this way, the internationalist faction of the POB was positioning itself with regard to the debate over the Burgos question.

Spaak found himself in a very unpleasant political position. One of the coalition government's members, the Catholic party, had made public in Parliament its opposition on the Burgos question against the stance of Spaak as Minister of Foreign Affairs. In addition to that, another coalition partner, the Socialist party, demonstrated again its internal division. A significant part within the party held as unacceptable the

\footnotetext{
${ }^{86}$ Ibidem., p. 5.

${ }^{87}$ Faut-il nommer un agent comercial à Burgos?, 1938, ADB, Reconnaissance de Burgos 11.169 (1).

${ }^{88}$ Bulletin Périodique de la Presse Belge, No128, 1938, BNF, p. 12, http://gallica.bnf.fr/ark:/12148/bpt6k64198853.item [accessed June 16, 2015].

89 “Ceux qui souhaitent voir le Duc d'Albe en Belgique”, Le Peuple, December 12, 1937.
} 
establishment of commercial relations with Franco's government. The internationalist faction had not given up its battle against Spaak's foreign policy yet, and the Burgos question revived the confrontation over Belgian foreign policy within the POB. The Minister of Foreign Affairs had won the support of the Catholic and Liberal parties, even Rex's support ${ }^{90}$, to implement the politique d'indépendence during 1936; he managed to get his policy accepted by the European powers in 1937, but he was still struggling for its acceptance in his party at the beginning of $1938^{91}$. He finally succeeded in imposing his view on the POB in March of that year ${ }^{92}$.

In addition to the political confrontation, the pressure exerted by the industrial sector also increased in 1938. After visiting some cities of Francoist Spain in March, a group of industrialists didn't hesitate to address their concerns about Spain to Spaak. They wanted Spaak to reconsider his position concerning relations with the Spanish territory controlled by the rebels. Regarding economic interests, in the judgement of the Belgian industrialists, the rebels were winning the war and, accordingly, were trying to prepare for the reconfiguration of the Spanish market that the outcome of the war would provoke $^{93}$.

Also, the traditional Catholic right imposed their vision of the conflict on the right wing of the political spectrum. Concerning the question about the recognition of the Burgos government, Franco was considered by many Catholics as the legitimate representative of the true Spain facing a republican government under the dominance of Moscow. Among Catholic politicians and voters, a narrative presenting the Spanish

\footnotetext{
90 “Le discours rexiste de M. Spaak", Le Pays Réel, July 24, 1936.

${ }^{91}$ Doc. 1938-02-22_bwp_BU.pdf, AMSAB-ISG, Comptes Rendus POB, pp. 526-528 http://opac.amsab.be/digital/42170095-A716-4FF7-9682-ACEA412A5E3D.pdf [accessed March 17, 2015].
}

See also Doc. 1938-02-23_bwp_AR.pdf, AMSAB-ISG, Comptes Rendus POB, pp. 14ª -29 http://opac.amsab.be/digital/157D3697-7378-414A-95A1-78629AF55055.pdf [accessed March 17, 2015 ].

92 Doc. 1938-03-04_bwp_AR.pdf, AMSAB-ISG, Comptes Rendus POB, pp. 25 $-27^{\mathrm{a}}$ http://opac.amsab.be/digital/DB5AFDEE-3F3F-4ABB-8046-E261A086E6F9.pdf [accessed March 17, 2015].

93 Mission d'industriels belges en Espagne nationaliste RV/YV/M/22, 1938, ADB, Reconnaissance de Burgos 11.169 (1), p. 3. 
Civil War as a crusade against Communism and for the defense of Christian civilization was pushed forward ${ }^{94}$.

Given the division within the POB regarding Burgos, political instability threatened the Belgian government again. A politically fractured POB placed itself in a different political position with regard to its government partners concerning the Spanish issue. To the socialist internationalists, the Burgos question appeared as the last opportunity to oppose Spaak's foreign policy. Burgos became a symbol of resistance to a policy that had been operating since 1936 -- a policy criticized again during the Congress of the POB that took place in November 1938.

So, at the Congress, Emile Vandervelde assumed the role of rapporteur on foreign policy. Officially, since June 1936 regarding foreign policy issues, the principle of collective security was the official position of the POB. Until the Conseil Général held in March 1938 not a single governing body of the POB had taken a stance against this. Despite the fact that the March resolution prioritized the presence of the POB in government, the official foreign policy position of the party was still the one approved by the party Congress in June 1936. So, the report presented by Vandervelde at the Congress focused on the polemic about the politique d'indépendence. Vandervelde took advantage of the impact provoked by the very recent change of mind of Spaak over the Burgos affair ${ }^{95}$ and unleashed an intense debate over Belgian foreign policy and the Burgos affair.

So, the positions defined within the POB in 1936 with regard to the European political polarization were in contradiction again in 1938. Within this political framework, the report La politique étrangère de la Belgique could be considered, since

\footnotetext{
94 Charles Terlinden, Une question à l'ordre du jour: La reconnaissance par la Belgique du Gouvernement National de l'Espagne, (Brussels 1937), P. 1. In KADOC, Archief M. De Brie, BE/942855/1834/6.

${ }^{95}$ Spaak, yielding to political pressure, sent a government official to Francoist Spain with the concrete task, to gather information about the real position of Belgian economic interests on Franco's territory. The report of this mission changed Spaak's mind about the necessity of sending a commercial representative to Burgos.
}

See AGR, Procès verbaux $d u$ Conseil des Ministres, No 4, 7/06/1938, PP. 423-424

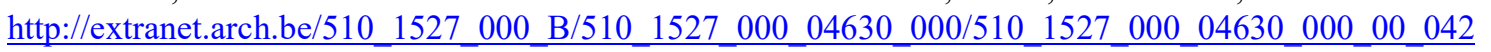
4.pdf\#search $=\% 22 \% 22$ [accessed July 10, 2016].

The report Delcoigne reproduced in Conclusions de mon enquête en Espagne, 1938, ADB, EspagneGuerre civile, Dossier Général 11.163 - Espagne 1938. 
he died shortly after its release, as Vandervelde's political testament ${ }^{96}$. In this text, the elderly POB leader denounced, and for the last time, the way the Belgian government was moving towards neutrality. It was a foreign policy that, in his opinion, implied concessions to the fascist powers ${ }^{97}$.

On the opposite side arose, again, the political position defended by Henri De Man and Paul-Henri Spaak. The former responded to Vandervelde through his report Pour une politique socialiste de Paix ${ }^{98}$. According to De Man, a policy of confrontation and provocation, as the one, in his opinion, advocated by the POB and the LSI, could only lead to war. According to this reflection, his solution to avoid Belgium being dragged into war was to avoid the confrontation through the implementation of a policy of peace avoiding the arms race and promoting social progress ${ }^{99}$. Therefore, while political efforts were addressed to guarantee social and economic progress for Belgian society, at the international level peace should be guaranteed among all the European states, no matter their political regime would be ${ }^{100}$.

These thoughts materialized in the support by one part of the POB of the Belgian government's decisions with regard to its foreign policy, and, specifically, to the Spanish Civil War and the Burgos affair ${ }^{101}$. De Man considered the government's political position to be realistic because, within the cabinet, the Socialists were in the minority. Also, because at a domestic level, the Belgian population's Catholicism was a very important political factor, and, consequently, the Spanish Civil War had become a very sensitive topic for the country - an issue threatening political and social stability. Furthermore, because he thought that Hitler's revisionism and territorial ambitions

\footnotetext{
${ }^{96}$ Emile Vandervelde, "La politique internationale", Documents et Discussions, IEV, Doe/Dis/276 Vol. XV No. 14, 86-101.

${ }^{97}$ Ibidem., p. 94.

98 Henri De Man, "Pour une politique socialiste de Paix", Documents et Discussions, IEV, Doe/Dis/276 Vol. XV No. 15, pp. 107-111.

${ }^{99}$ Ibidem., p. 109.

${ }^{100}$ Ibidem., p. 110.

101 AGR, Procès verbaux $d u$ Conseil des Ministres, No32, 25/10/1938, pp. 878-879 http://extranet.arch.be/510_1527_000_B/510 1527_000_04631_000/510_1527_000_04631_000_00_038 8.pdf\#search $=\% 22 \% 22$ [accessed July 10, 2016].
} 
could be contained through negotiations, he was confident that coexistence with Fascism was possible through the promotion of peace ${ }^{102}$.

After a succession of POB congresses that threatened the stability of Spaak's government through the repercussions generated by the Congress' refusal to send a commercial representative to Burgos ${ }^{103}$, the socialist party resolved the internal tensions by approving the politique d'indépendence and by prioritizing its presence at the coalition government over the decision taken by this same government concerning the Burgos affair ${ }^{104}$. This decision opened the way to the recognition in March 1939 of Franco's government by Belgium.

So, again in 1938, the political fracture within the POB, caused by both the implementation of the politique d'indépendence and the effects of the Spanish Civil War within the Socialist ranks, generated tensions and political controversies, affecting the party's position as a member of the coalition government. On the other hand, the Liberals and the Catholics, with a few exceptions, took a position in favor of sending a commercial representative to Burgos. Therefore, if the Congress of the POB had not relinquished its positions concerning the Burgos affair, a government crisis could have occurred, and it would have provided the Rex with an excellent political opportunity to enter government or take power ${ }^{105}$.

So, ultimately, both the respect for the stability of the government by the POB's internationalist faction and the conviction that the POB should be part of the coalition government in order to guarantee the implementation of its reformist political agenda, prolonged the Burgos crisis by avoiding the resignation of the socialist ministers ${ }^{106}$. On the other hand, however, it also prevented a traumatic outcome of the issue in the form of a government crisis and further unpredictable consequences.

\footnotetext{
102 Documents et Discussions, IEV, Doc/Dis/276 Vol. XV No.15, p. 106.

103 “À l'unanimité moins 7 voix et 4 abstentions le Congrès adopte une résolution sur la question de Burgos”, Le Peuple, November 7, 1938; See also Le Peuple, December 6, 1938.

104 “Le 57e Congrès du POB”, La Libre Belgique, November 8,1938.

${ }^{105}$ Doc. 1938-11-30_bwp_AR.pdf, AMSAB-ISG, Comptes Rendus POB, p. L.16B http://opac.amsab.be/digital/15E9CB76-88F3-43F0-BAF7-28A75A4498BC.pdf [accessed March 17, 2015].

${ }^{106}$ Doc. 1938-12-08_bwp_BU.pdf, AMSAB-ISG, Comptes Rendus POB, p. 882 http://opac.amsab.be/digital/8ADEC2D0-6184-415E-80E4-29F3E1851E85.pdf [accessed March 17, 2015].
} 


\section{CONCLUSIONS}

Belgian liberal democracy was, indeed, marked by the experiences of the Great War. The country had witnessed destruction and occupation and had become a battlefield in the conflict. This constituted such a powerful legacy that it influenced Belgian foreign policy during the whole of the Interwar period. Belgian diplomacy sought to avoid by any means the country becoming involved in a new war. First, Belgium integrated the collective security system set in place by the Versailles and Locarno treaties. Through Locarno, Belgium accepted mutual guarantees with Germany, France, the United Kingdom, and Italy. When, however, Germany violated and denounced the treaty by occupying the Rhineland on March 7, 1936, Belgium felt threatened, and its diplomacy started to introduce a major change in foreign policy.

In parallel with this, the Belgian political panorama witnessed the emergence of extreme political alternatives. The PCB increased from three to nine deputies in the elections held on May 24, 1936. Rex gained 21 seats. Therefore, Catholics, liberals, and socialists were obliged to form a coalition government in order to guarantee political stability and to contain Rex's aspirations to hold power. Although the Belgian state was challenged during the second half of the 1930s by an authoritarian alternative, the legacy from the years preceding the Great War and the culture of coalition proved to be solid.

Within this political framework, on July 18, 1936 a part of the Spanish Army carried out a coup d'état against the legitimate government of the Spanish republic. The coup failed and opened the door to a civil war that lasted almost three years. This research offers a comprehensive account of how the Spanish Civil War influenced political life in Belgium.

After Germany's renunciation of the Locarno Treaty, a negotiation process started to try to reach a new security pact in Western Europe. Belgium's newly appointed Minister for Foreign Affairs, Paul-Henri Spaak, took advantage of this circumstance to reformulate Belgian foreign policy. Belgian diplomacy relinquished the principle of collective security and started to shift towards neutrality. This implied a break with the obligations assumed by Belgium within the framework of the Locarno 
Treaty and, after the German renunciation of the treaty, by virtue of the London agreements of March 19, 1936.

The new Belgian foreign policy to be implemented, la politique d'indépendance, was officially announced on July 20, 1936, not more than two days after the military coup in Spain. So, the effects of the Spanish Civil War on Belgium's politics have to be understood in view of the Locarno negotiations. Belgium wished to redefine a new international status for herself in this negotiation process. The Spanish Civil War became an obstacle for Belgian efforts to achieve this goal, their desired new international position. Therefore, Spaak acted with extreme caution when positioning Belgium with respect to the Spanish war. He renounced taking a political initiative and followed the path taken by the major powers in Europe by containing the Spanish conflict within Spanish borders. Belgium stuck to the Non-Intervention Pact because it conformed to its new foreign policy.

On the other hand, this politique d'indépendence was considered by the Belgian government and by Spaak himself as the only policy capable of ensuring internal political stability. Given the ideological divisions between the Belgian political actors, it was namely a neutral position towards the Spanish war that was considered by the government as the guarantee for political stability.

This view was not shared by all. Communists and an important part of the POB considered the politique d'indépendence to be a mistake. They thought that to renounce the principle of collective security meant removing an important barrier on the way to a new European war. They warned about the real intentions behind German foreign policy and opposed the implementation of the new Belgian foreign policy. Communists and some of the socialists saw the Spanish Civil War as an opportunity to oppose Spaak's political action. According to their position, the conflict was exposing the real intentions of the fascist powers.

So, the Spanish Civil War, as a political issue in Belgian politics, was linked to the debate on the new foreign policy. The politique d'indépendence of the Belgian government was determined by the course of the Spanish conflict and its influence on European politics. Further, the Spanish Civil War provoked various forms of political division within Belgian society. The Spanish Civil War appeared as such a controversial 
topic in the Belgian internal debate on foreign policy that it allowed Rex, in its striving for political domination, to excite the political climate. Conflicts arose within the POB that posed a threat to the stability of the coalition, and divisions appeared within Belgian society in general with regard to the perception of the conflagration and sympathies toward the contenders. Reports of atrocities against the Church, that were triggered among the Republicans during the first weeks of the war, were crucial to consolidate catholic and, in general, liberal sympathies towards the rebels. On the other hand, Franco's repression and the fascist powers' intervention in the war led communists and socialists to side with the cause of the Spanish republic. Both parties denounced the abandonment of the legitimate Spanish government by European powers, and some of their members tried to support the republican war effort by solidarity initiatives or by direct intervention in the conflict.

In conclusion, the Spanish Civil War appears in this research as an event that can be seen as playing an important role on all three levels of the analysis detailed in the introduction. First, it represents a manifestation of the dynamics of Interwar history generated by the emergence of extreme political alternatives in European politics; secondly, it appears as an influential factor within Belgium's political life - in relation to the implementation of foreign policy, to the political division within the POB, to the way Belgian political parties contributed to maintain political stability facing this challenge, and to Belgian society as a whole - and, finally, influencing personal decisions made by individual actors involved in Belgian politics. As an example of the latter, the case of Paul-Henri Spaak can be recalled. In his autobiography, Spaak wrote that he was forced to implement the politique d'indépendence ${ }^{107}$.

However, it has been proven by the primary evidence used to build this narrative that, in fact, Spaak implemented his foreign policy by conviction and not by obligation - a decision leading to the division within the POB, Belgium's withdrawal from the Locarno Treaty, and the participation in the Non-Intervention policy. He acted according to the attitude that generally characterized the thinking of Belgian politicians: the fear of a "new 1914". From this point of view there is nothing to be reproached. Spaak's arguments to implement and defend the politique d'indépendence were

\footnotetext{
${ }^{107}$ Paul-Henri Spaak, Combats..., op. cit. p. 29.
} 
plausible and logical, given the international situation of the late 1930s. On the other hand, what can be reproached is his attempt to justify his decisions through false assertions. He played a major role in politically deactivating, in general, the alternative interpretation of the international situation embodied by Vandervelde and his followers, which also meant a different political approach to facing Interwar political challenges.

Thus, this work offers a comprehensive account of the impact of the Spanish Civil War on Belgian politics, while also contributing to the Spanish historiographical debate by demonstrating that the political alternatives represented by the forces fighting in Spain were also present in Belgium. That is how the Spanish conflict's effects transcended Spanish borders and were felt in Belgium, as well. There are general historical structures in Interwar Europe that explain these interconnections. The developments in Spain cannot, therefore, be classified as an exception in Europe, but rather a manifestation of the general historical tendencies of the period.

\section{BIBLIOGRAPHY}

Casanova, Marina, "Las relaciones diplomáticas hispano-belgas durante la guerra civil española: el caso del barón Borchgrave". Espacio, Tiempo y Forma, Serie V, $H^{a}$ Contemporánea, t. V, (1992): pp. 293-302.

Casanova, Julián, España partida en dos, Barcelona: Crítica, 2013.

David, Eric, "La condition juridique des volontaires belges pendant la guerre d'Espagne (1936-1939)". Revue Belge d'Histoire Contemporaine 1-2 (1987) : pp. 39-80.

De Man, Henri, Après Coup, Brussels: Toison d'Or, 1941.

Delwit, Pascal, La vie politique en Belgique de 1830 à nos jours, Bruxelles: Editions de l’Université de Bruxelles, 2012.

Fernández Soriano, Víctor, "Bélgica y la Guerra Civil: el impacto del conflicto español en la política y la diplomacia de una pequeña potencia". Cuadernos de Historia Contemporánea, vol. 29, (2007): pp. 219-233.

Gotovitch, Jose, "La Belgique et la guerre civile d'Espagne: Un état des questions". Revue Belge d'Histoire Contemporaine 3-4 (1983): pp. 497-532.

Lépine, Nicolas, "Le socialisme international et la guerre civile espagnole", $\mathrm{Ph}$. D. diss., Université de Laval, 2013. http://hdl.handle.net/20.500.11794/24897 
Luebbert, Gregory M., Liberalism, Fascism or Socialdemocracy: Social clases and the Political Origins of Regimes in Interwar Europe. New York: Oxford University Press, 1991.

Moradiellos, Enrique, El reñidero de Europa. Las dimensiones internacionales de la Guerra civil española, Barcelona: Ediciones Península, 2014.

Pfeiffer, Robert et Ladriere, Jean, L'aventure rexiste, Bruxelles: Pierre de Meyer (ed.), 1966.

Spaak, Paul-Henri, Combats Inachevés, París: Fayard, 1969.

Steiner, Zara, The triumph of the dark. European international history 1933-1939, Oxford: Oxford University Press, 2011.

Tilly, Charles, Las Revoluciones Europeas, 1492-1992, Barcelona: Crítica, 2000.

Van Zuylen, Pierre, Les mains libres. Politique extérieur de la Belgique 1914-1940, Brussels: L'Edition Universelle, 1950.

Vandervelde, Émile, Carnets 1934-1938, Paris: Les Editions Internationales, 1966.

\section{ARCHIVES}

AMSAB-Institut d'Histoire Sociale (AMSAB-IHS)

Archives Diplomatiques Belges (ADB)

Archives Généraux du Royame (AGR)

Archives de l'ULB (AULB)

Bibliothéque Nationale Française (BFN)

Bibliothéque Royale de Belgique: Collection Journaux

Centre des Archives Communistes en Belgique (CArCoB asbl)

Historical Archives of the European Union (HAEU)

Institut Émile Vandervelde (IEV)

Documentation and Research Center on Religion, Culture and Society (KADOC)

The National Archives (TNA) 